is in millimetres. The rules can be supplied with the plain scales either in inches or millimetres, and in the specimen submitted to you the mix up is the result of accident, and not perversity.

All Saints' Works, Derby May zo.

JoHn Davis AND Son.

\section{THE LOWER VERTEBRATES. ${ }^{1}$}

"L VERYTHING comes to him who waits"! Certainly the patience of many has been sorely tried by the long advent which has preceded the appearance of this last volume of the Cambridge Natural History. Students of the lower vertebrates will be naturally predisposed to accord it a favourable reception, inasmuch as its predecessors have presented such a high standard of excellence. If in some respects a closer acquaintance reveals some cause for complaint it will be admitted that, surveyed as a whole, both authors and editors alike are to be congratulated on having produced a work of sterling merit.

The groups dealt with in this volume are not only of the highest scientific interest and importance, but they present more than ordinary difficulties to be investigated, and these difficulties are materially increased when stern necessity compels the several contributors to condense their work within the smallest possible limits. Happily this task has fallen on the right shoulders, and all must admire the way in which it has been performed.

The first chapter of this buok has been written by Dr. S. F. Harmer, and deals with the Hemichordata, a group which includes creatures of the existence of which the layman has never heard! Yet their importance in the scheme of evolution is of the highest, inasmuch as they bridge the gap for us between vertebrates and invertebrates.

The true nature of these worm-like and tubicolous animals has been determined only after the most laborious and painstaking research, in which Dr. Harmer, the author of this chapter has borne a very conspicunis share. Though the vertebrate affinities of the worm-like Balanoglossus were first hinted at by Kowalewsky in. I866, it was not until $\mathrm{x} 886$ that this relationship was really demonstrated: a triumph achieved by Bateson. Forming at first a branch by itself of the vertebrate phylum, Balanoglossus has since lost something of its unique character by the discovery that certain other tubicolous formsRhabdopleura and Cephalodiscus-would have to be promoted to share this position, though to the ordinary observer nothing could be less like a vertebrate in appearance! This advance in our knowledge was made by the author of this chapter; and he has now still further extended the boundaries of this group so as to include Phoronis, an animal hitherto referred both to the Gephyrea and to the Polyzoa.

Although our knowledge of the Tunicates-those " common objects of the sea-shore," known as the "sea-squirts" -has been accumulating for something more than two thousand years, it was not until the middle of the eighteenth century that any real progress in the study of these creatures was made. And yet a century passed before the appearance of Kowalewsky's epoch-making work, which showed conclusively the astonishing fact that these shapeless jelly-bags were really kith and kin of the vertebratesbut degenerates!

No other group of animals is so all-embracing in the nature of the phenomena it displays. As the author remarks, "They demonstrate both stable and

1 " Hemichordata, Ascidians and Amphioxus, Fishes." By Drs. Harmer, Herdman, Bridge and G. S. Boulenger. The Cambridge Natural History, vol. vii. Pp. xvii+760. (London: Macmillan and-Co., Ltd. x904.) Price 175 . net. variable species, monophyletic and polyphyletic graups. They exhibit the phenomena of gemmation and of embryonic fission, of polymorphism, hibernation, alternation of generations, and change of function. They have long been known as a stock example of degeneration; but in fact they lend themselves admirably to the exposition of more than one 'chapter of Darwinism." ",

Prof. Herdman has made this group peculiarly his own, and the editors are to be congratulated in having secured him to write this chapter. Nowhet else will the student find so icomplete and altogether adimirable a summary of this most difficult and puzzling group of animals:

In dealing with amphioxus Prof. Herdman has been hampered by lack of 'space. This seems evident, not from the absence of any essential facts in his account, but from the condensed fashion in which the facts are presented. To the majority of those who will use this book this is perhaps of no great moment, but others, we imagine, will fail to appreciate the full

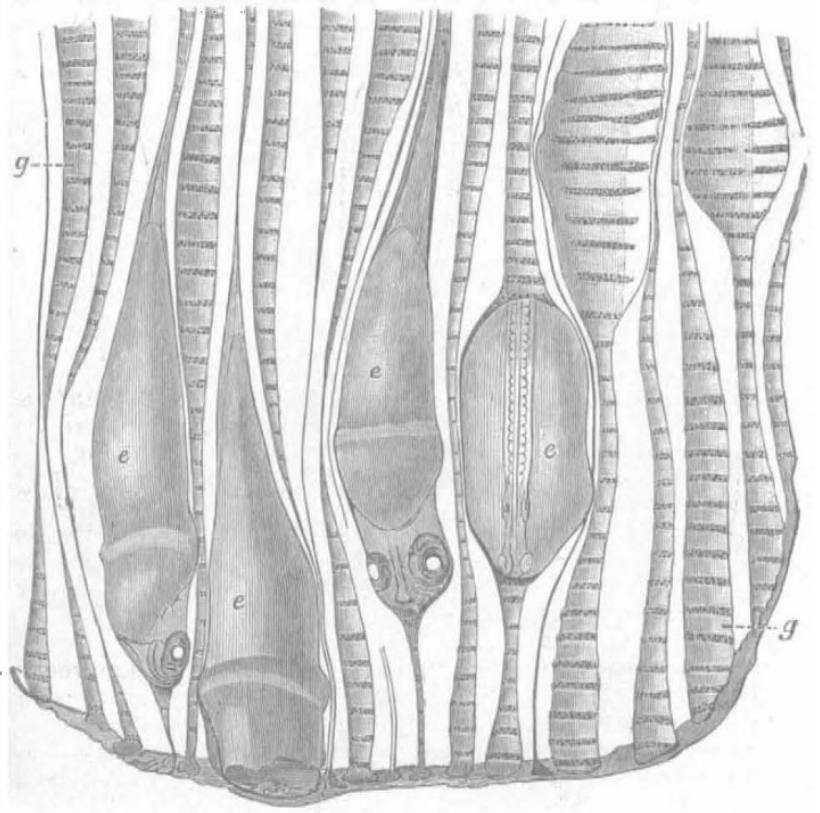

F1G. 1.-Embryos of Rhodeus amurus in the gill-cavities of Unio. e. Embryos; $g$, , inter-lamellar cavities. From the "Cambridgé Natural History."

importance of some phases in the life history of this "weed in the vertebrate garden."

The remarkable ciliated condition of the embryonic and early larval stages is, for example, all too lightly passed over. Attention is not called to the importance of the fact that in the free-swimming, ciliated larva we have a connecting link between vertebrates and invertebrates. His reference to the existence of cilia is of the briefest. He remarks simply, that "the embryonic stages being passed through during the night ... the larva hatched in the early morning," and then, on the next page, continues, "The epiblast cells become ciliated all over the surface, so that the embryo rotates within the thin covering which still surrounds it." Passing on to describe the metamorphosis of the embryo he goes on to say that "When it has (developed) about five pairs of mesoblastic somites, it breaks out of its covering, and becomes a free swimming larva." Probably no living biologist knows more of amphioxus than Prof. Herdman. Thus, then, this lack of emphasis of a really important feature must be attributed to the fact that he had to 
compress his account unduly. As a matter of fact the whole history has been crowded into something less than eight and twenty pages, including illustrations!

This condensation is evident throughout each of the chapters so far noticed, and probably accounts for the absence of anything in the shape of an historical review of the evolution of our knowledge of these obscure groups. Surely this is to be regretted, inasmuch as this is a volume which will serve as the main source of information for many generations of students; and it would be well to place before them some idea of the laborious and patient work which has been spent by. others in building up the knowledge which is theirs to-day. Such a review would serve a double purpose. It would keep alive the memory of those whose names are all too soon forgotten, and it would serve as an incentive to further work.

Probably this survey would not have been wanting, but for the fact that some two hundred and eighty of the seven hundred and twenty-seven pages which mak' up the book are devoted to the introduction on fishes! This is not as it should be; on this account serious

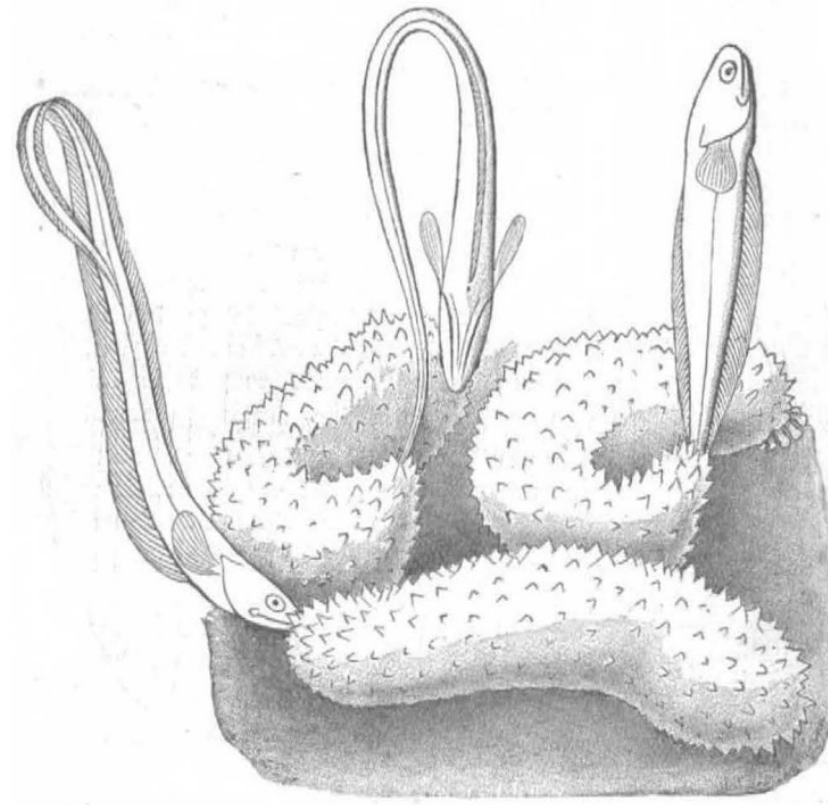

Fig. 2.-Fierasfer acus penetrating into Holothurians; two-fifths natural size. From the "Cambridge Natural History."

injury has been done both to the chapters which precede it and those which follow. Much of this introduction could have been dispensed with, inasmuch as matters of a purely physiological import are now included, and these are outside the scope of this volume. Lengthy as it is, it is yet incomplete. Morphological questions that should have found a place here are either ignored or dismissed in a few lines. If these had taken the room of the matter to which we object some justification might have been pleaded for the condensation of the exceedingly valuable chapters which we have just noticed. Yet, in spite of these drawbacks, this introduction will prove most valuable to those who use this volume as a text-book, and there is no doubt but that it will be widely read and highly valued in the various science schools throughout the kingdom.

It is a pity that more figures of larval fishes were not given in this introduction, designed to illustrate the remarkable transformations which some species especially undergo from the time of hatching to maturity.

$$
\text { No. I } 857 \text {, YOL. } 727
$$

In regard to the Cyclostomata it is curious that no mention is made of the extraordinary slime-secreting powers of the Myxinoids. True, he refers to "a row of mucous secreting sacs along each side of the body," but this scarcely does justice to the case; inasmuch as an instance is on record of a single individual which, placed in three or four cubic feet of water, converted the whole into a jelly-like mass, which could be lifted out with a stick! The specific name of Myxine glutinosa has reference to the old belief that the fish possessed the power of turning water into glue.

Prof. Bridge solves the difficulty as to the systematic position of Palæospondylus by placing them in a sort of limbo designated an "appendix to the fishes."

In this same appendix it is somewhat surprising to find not only the Ostracoderms, but the Arthrodira! As touching the former Prof. Bridge may claim that he errs, if erring he is, in good company, since so eminent an authority as Dr. Smith Woodward refuses to admit these "bones of contention" into the class Pisces. But we object to the hesitancy displayed by Prof. Bridge; he will neither call them fishes nor allow them to rank as a separate class (Agnatha), as Dr. Woodward has done. But surely there can be no question as to the class, at least, to which the Arthrodira belong? According to the most recent views they are to be regarded as Dipnoans.

In spite of these drawbacks Prof. Bridge's contribution to this volume is a valuable one. He has brought together a vast amount of information, much of which is the result of his own researches. Where he has had to draw upon the work of others he has for the most part selected of the best. Our chief complaint is that he is so meticulously exact.

The Teleostei, from a systematic point of view, are described by Mr. E. A. Boulenger, and he has brought to bear upon this most difficult task an unrivalled knowledge, tempered with rare skill and judgment. The classification which has been generally in use in this country for the last thirty years is now replaced by one which aims at being phylogenetic-the true basis of all systematic work. Although we believe Mr. Boulenger has improved on this arrangement in some minor details since passing the final proofs of his work some three years ago, it may be accepted as practically representing his views on this subject.

As he remarks, "Out of some 12,000 wellestablished species of fishes known to exist at the present day, about $I I, 500$ belong to this order (Teleostei). The classification of such an array of forms is, of course, a matter of great difficulty, and gives scope for much difference of opinion among those who have attempted to grapple with the subject." The basis of this classification differs from that usually employed in other groups of vertebrates, inasmuch as it rests on osteological characters, in so far as families and higher groups are concerned.

The reader of this notice may imagine, from our ominous reference to dry bones, that Mr. Boulenger's contribution is of the nature of a dull and tiresome catalogue. We hasten to remark, therefore, that this element is effectually masked by the introduction of all the more important facts concerning the lifehistories of the various species which have come within the author's province. These facts form most fascinating reading, and will appeal to a large number of people other than professed students of zoology. Do fishes sleep? is a question often asked. Although answered in the affirmative some, eight and thirty years ago by Mobius, the fact has remained ever since practically buried in the German publication in which it appeared. Mr. Boulenger is apparently the first to give it circulation in a text-book. A species of Wrasse 
confined in an aquarium, he points out, was observed by Mobius to seek a sleeping place at night, and to lay itself down to rest on one side. The psychologist and the student of evolution will find in these chapters of $\mathrm{Mr}$. Boulenger a perfect mine of information. No more instructive lessons in adaptation can be gathered than from the descriptions and figures illustrating this part and certain sections of Prof. Bridge's workas witness the text cuts given herewith.

\section{ABORIGINAL INDIA. ${ }^{1}$}

$\mathrm{M}^{\mathrm{R}}$ BRADLEY-BIRT'S book dealing with the Santal Parganas merits the success achieved by his former volume on Chota Nagpore. This time, he lays his scene in the mountáinous, forest-clad outlier of the Vindhyan range, which stands like an island in the midst of the great Gangetic plain. Dominating the great waterway which leads from the borders of the Punjab to the Bay of Bengal, it has for centuries been the stronghold of the aboriginal tribe who sought refuge in it from the Aryan flood descending from the north-west on the fertile plains of Bengal. From his almost inaccéssible stronghold, the Paharia looked down upon the coming and going of the Hindu, the Pathan, and the Moghul. Empires rose and fell before his very eyes whilst he; hating the foreigner of every race and creed, remained wrapped in his primitive barbarism, a hunter living on the produce of the surrounding forest, not to be starved into submission, because he had no need of the produce of the plains. His only dealings with successive invaders were when he swooped on the villages below, killing and robbing their inhabitants, or cutting off travellers and the camp followers of passing armies." Neither Hindu nor Mahomedan could subdue him by main force without extravagant loss.

Attempts to bribe the mountaineer with land around the mountain failed, for he did not care to cultivate, and the keeping of a bargain with the hated foreigner formed no part of his moral code.

At last appeared the British, whose fair complexion impressed the Paharia with an idea that they were of higher origin than the earlier conquerors. In Augustus Cleveland came a man who found a way to tame the savage, to enlist his sympathy, and to offer an outlet for his martial instincts. Some of the Paharias were enlisted as an irregular force, whilsi an endeavour was made to isolate the rest in a ring of neutral territory, from which the Hindu and the Mahomedan of the plains were to be excluded. Much of Cleveland's good work was undone by a successor of sterner and less considerate temperament. The solution of the difficulty was finally found, about $18_{30}$, when a wandering branch of the Santals, another aboriginal tribe, appeared upon the scene and eagerly accepted the land below the hills which the Paharia, refusing for himself, made untenable for the plainsman. The Santal, an enthusiastic though uncivilised cultivator, recognised as a kinsman by the Paharia,

1 "The Story of an Indian Upland." By F. B. Bradley-Birt. Pp.xvi+ 354. (London: Smith, Elder and Co., rgo5.) Price i2s. 6d. net. formed an efficient buffer between the hillman and the inhabitants of the surrounding plain. The Santal, in turn, gave trouble in 1856 , when he broke into rebellion directed against the peaceful penetration of the moneylender and the landgrabber.

It is with these two aboriginal tribes that $\mathrm{Mr}$. Bradley-Birt chiefly deals. As men, they are perhaps more interesting to the ethnologist and the philologist than to the ordinary student of human nature, but the author has succeeded in enlisting such interest as we can spare to one tribe still in the purely agricultural stage, and to another which has scarcely as yet progressed beyond that of the hunter.

His picture of village life on, and at the foot of, the Rajmahal hills glows with local colour and swims in the atmosphere of the jungle and the plain. It was scarcely necessary for him to assure his reader that most of the book was written in camp, in the midst of the Paharias and the Santals. As one reads, one seems to inhale the fresh, crisp air of an Indian cold weather morning, or to pant in the heavy atmosphere of the forest as the line of Paharia hunters presses,

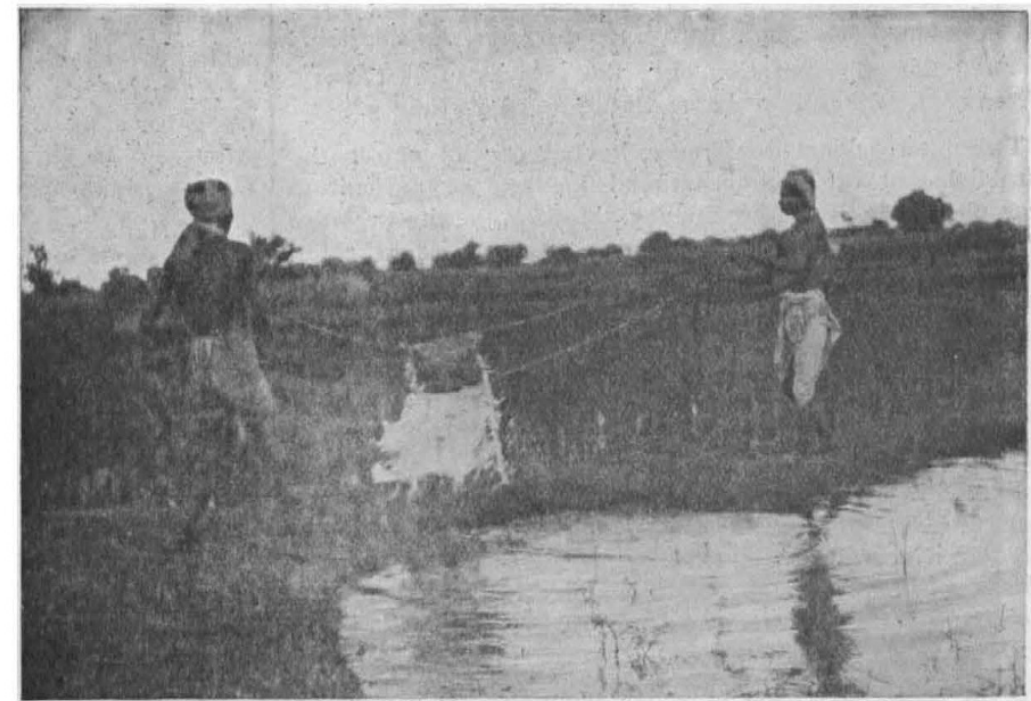

F1G. I.-A Primitive Mode of Irrigation. From Bradley-Birt's " Story of an Indian Upland.

shouting and slaying, through the dense undergrowth.

Much that Mr. Bradley-Birt describes, or depicts in his photographs, is not peculiar to the Santal Parganas. The primitive mode of irrigation, with basket swung by two men, which forms the subject of the illustration here reproduced, is still practised by millions who have never heard of the Santals, or been within a thousand miles of their home. All over India the cultivator watches his crops at night from a rough platform raised on a ricketty scaffolding of bamboos. Sometimes it happens, in regions not unlike the Rajmahal hills, that the vigil ends in a tragedy, when the sleepy watcher is torn from his post by the man-eating leopard. But the inclusion of these incidents in no way detracts from the charm of the picture of simple village life, a life of agricultural labour tempered by feasting and dancing in seasons when there is nu labour to be performed.

The Paharias' rude religion has drawn nothing from Hinduism or Islam. The Santal equally professes his separation from those creeds, but his love of pleasure has induced him to adopt some of the Hindu festivals, for instance the Jatra, which he celebrates in February. 